\title{
A simplified maturity index to quantify the development stage of perennial ryegrass (Lolium perenne L.) and its relationship with yield and nutritive value
}

\section{Ein vereinfachter Index zur Quantifizierung des Entwicklungsstadiums von Englischem Raygras (Lolium perenne L.) und dessen Zusammenhang mit Ertrag und Nährwert}

\author{
Heba Salama ${ }^{2,3}$, Marc Loesche ${ }^{2}$, Antje Herrmann ${ }^{2}$, Friedhelm Taube ${ }^{2}$, Martin Gierus $^{12}$ *
}

\footnotetext{
${ }^{1}$ Institute of Animal Nutrition, Livestock Products and Nutrition Physiology (TTE) Department of Agrobiotechnology, IFA-Tulln, University of Natural Resources and Life Sciences Vienna (BOKU), Muthgasse 11, 1190 Wien, Austria

${ }^{2}$ Grass and Forage Science/Organic Agriculture Group, Institute of Crop Science and Plant Breeding, University of Kiel, Hermann-Rodewald Straße 9, 24118 Kiel, Germany

${ }^{3}$ Crop Science Department, Faculty of Agriculture, Alexandria University, Aflaton St. - ElShatby, Alexandria, Egypt

* Corresponding author: martin.gierus@boku.ac.at
}

Received: 19 March 2017, received in revised form: 17 July 2017, accepted: 24 July 2017

\begin{abstract}
Summary
Plant maturity substantially influences the yield and quality performance of grasses. Grass phenology is often not considered objectively to evaluate the new genotypes prior to registration. Measuring the mean stage by count (MSC) is time consuming, and simplified approaches are, therefore, required. Twenty diploid, intermediate heading Lolium perenne L. genotypes were evaluated in a 2-year field study in Northern Germany for yield and the content of Neutral Detergent Fiber (NDF), Acid Detergent Fiber (ADF), Acid Detergent Lignin (ADL), and digestible organic matter (DOM). Data from the first and second cut, each comprising three sampling dates, were included in this study. A simplified maturity index (SMI8), expressing the percentage of tillers at or beyond the boot stage, from MSC was derived. This index resulted in similar correlations with yield and quality parameters compared to MSC but is easier to use and less laborious. The SMI8 reduced the variations among genotypes, as for the first cut NDF and ADF content, where the genotype effect disappeared after considering SMI8 as the covariable. Moreover, the ranking of the genotypes was slightly modified for most studied traits, indicating that a large part of the variations in the studied parameters was caused by variations in maturity.
\end{abstract}

Keywords: perennial ryegrass, development stage, nutritive value, covariable, genotype

\section{Zusammenfassung}

Das Entwicklungsstadium zum Erntezeitpunkt von Gräsern hat zwar einen entscheidenden Einfluss auf die Futterqualität, wird bei der Sortenprüfung aber meist nicht objektiv berücksichtigt. Eine Möglichkeit dazu ist die zeitaufwändige Bestimmung des "mean stage by count" (MSC), wünschenswert wäre allerdings eine rasch durchführbare, vereinfachte Methode. Zwanzig diploide Sorten des mittelfrühen Sortiments von Lolium perenne L. wurden dazu in einem 2-jährigen Versuch in Norddeutschland untersucht. Ertrag, neutrale Detergenzienfaser (NDF), saure Detergenzienfaser (ADF), Lignin (ADL) und in vitro Verdaulichkeit der organischen Masse (VOM) wurden an Proben aus dem ersten und zweiten Aufwuchs eines Jahres, an jeweils drei Ernteterminen, bestimmt. Ein vereinfachter Index (SMI8) zur Bestimmung des Entwicklungsstadiums wurde aus dem MSC abgeleitet. Der SMI8 führte zu ähnlichen Zusammenhängen mit Ertrag und Nährwert, wie bei MSC beobachtet, allerdings mit geringerem Aufwand zur Bestimmung des SMI8 im Vergleich zu MSC. Der SMI8 führte zu geringerer Variation zwischen den Sortenkandidaten, wie z.B. im ersten Schnitt für den Gehalt an NDF und ADF. Dies hat zur Folge, dass die Kovariable im statistischen Modell zu einer Verschiebung der Reihung der Sortenkandidaten für die meisten erfassten Merkmale führte. Diese Verschiebung weist wiederum auf eine Variation hin, welche mit dem Entwicklungsstadium zu erklären ist.

Schlagworte: Englisches Raygras, Entwicklungsstadium, Nährwert, Kovariable, Genotyp 


\section{Introduction}

Accurate and easy identification of the growth stage of a grass sward is critical to many forage breeding and management decisions. Quantity and quality of forage grasses are strongly affected by plant morphology (Moore and Moser, 1995). Some forage quality traits, such as crude protein and fiber, change unfavorably with advancing maturity (Simon and Park, 1983). Many previous studies have been conducted with the common goal to quantify the developmental stages of cool-season (Haun, 1973; Simon and Park, 1983; Sweet et al., 1991; West et al., 1991) and warm-season (Moore et al., 1991; Sanderson, 1992; West, 1990) grasses. A considerable attempt in characterizing the phenological development of perennial grasses was done by Simon and Park (1983), who described a scheme for classifying growth stages. Their system was based on that developed by Zadoks et al. (1974) for cereals with some modifications to account for developmental stages unique to perennial grasses. Although the Simon and Park (1983) system was adopted by many researchers it proved to be complex to be applied in the field. In the early 1990s, another system for describing the phenological development of perennial forage grasses has been developed by Moore et al. (1991). Furthermore, they recommended using the mean stage by count (MSC), introduced by Kalu and Fick (1981) for alfalfa, as a numerical maturity index for quantifying the developmental morphology of a population of tillers. A random sample of tillers should be collected from the sward and each tiller classified according to its developmental stage, and the MSC value is then calculated as the weighted mean stage. A close relationship between MSC and the nutritive value of grasses is well documented (Van Soest, 1994; Brueland et al., 2003).

In breeding for improved yield and forage nutritive value of grasses, the maturity indices can be used as a covariate to adjust the performance of diverse cultivars under constant maturity levels (Van Santen and Casler, 1990b). However, phenology is often not considered. In Germany for instance, the performance trials for Value of Cultivation and Use (VCU), which are a prerequisite for the registration of new grass cultivars, are conducted separately for early, intermediate and late heading genotypes, but do not take into account the maturity variation among the genotypes within a group. Situations similar to Germany are observed in other west and east European countries, like France, the Netherlands, Denmark, Switzerland, Poland and the Czech Republic. To date, there is no information available on the extent to which the non-consideration of maturity aspect in the VCU trials of perennial grasses may result in a biased evaluation, especially considering the negative consequences on the estimation of the nutritive value. The objective of the present study was to develop a simplified comprehensive numerical index for quantifying the phenological development of perennial grasses, which is less time consuming and can be applied more easily in the field, and at the same time provides a similar relationship to yield and prominent quality traits as the commonly used MSC.

\section{Materials and Methods}

\subsection{Plant material, site and design of experiment}

The study was conducted as a 2-year field experiment at the Hohenschulen experimental station $\left(54^{\circ} 18^{\prime} \mathrm{N}, 9^{\circ} 58^{\prime} \mathrm{E}\right.$, altitude: $24 \mathrm{~m}$ ) of the Christian-Albrechts-University, Kiel, Northern Germany. The site is characterized by its sandy loam soils. Average annual temperatures were $10.0^{\circ} \mathrm{C}$ in 2006 and $9.9^{\circ} \mathrm{C}$ in 2007 . The year 2006 was characterized by lower total annual precipitation, amounting to $707 \mathrm{~mm}$. Higher total annual precipitation values were recorded in the second experimental year (2007), amounting to $926 \mathrm{~mm}$ for the experimental site.

Twenty diploid intermediate-heading perennial ryegrass (Lolium perenne L.) genotypes (Table 1), which provide the range of phenological variation found in the corresponding maturity group, were evaluated with respect to their yield and quality performance. Three replicated $3 \mathrm{~m}$ by $6.5 \mathrm{~m}$ plots per genotype were sown in a randomized complete block design.

\subsection{Management and sampling}

The experimental plots were sown on September 6 the year before sampling and the sampling was performed in the following two years $(2006 / 2007)$. All plots were treated similarly and received $300 \mathrm{~kg} \mathrm{~N} \mathrm{ha}^{-1}$ in the form of calcium-ammonium nitrate, split into four applications, namely 100 , 80, 80 and $40 \mathrm{~kg} \mathrm{~N} \mathrm{ha}^{-1}$ applied before the first, second, third and fourth harvests, respectively. In addition, $80 \mathrm{~kg}$ $\mathrm{P}_{2} \mathrm{O}_{5} \mathrm{ha}^{-1}$ were applied at one dose in spring of each year. A potassium fertilizer $\left(40 \% \mathrm{~K}_{2} \mathrm{O}, 6 \% \mathrm{MgSO}_{4}, 4 \% \mathrm{~S}, 3 \% \mathrm{Na}\right)$ was given at the rate of $360 \mathrm{~kg} \mathrm{~K}_{2} \mathrm{O} \mathrm{ha}{ }^{-1}(200$ and $160 \mathrm{~kg}$ $\mathrm{K}_{2} \mathrm{O}$ ha $^{-1}$ before the first and third harvests, respectively). Folicur $^{\oplus}$ (1-(4-chlorophenyl)-4,4-dimethyl-3-(1,2,4-tria- 
zol-1-ylmethyl)pentan-3-ol) was sprayed against crown rust (Puccinia coronata) at a rate of $0.71 \mathrm{ha}^{-1}$ two weeks after each harvest beginning from the second one.

The harvest dates for the two experimental seasons are presented in Table 2. The plots were managed with four cuts, and for the first and second cut, three sampling dates were set, to account for the variation within genotypes and sampling dates within the first cut. The first and third sampling dates within the first and second cuts were performed at a smaller area in the plot, as the second sampling corresponds to the four-cut management. The first sampling for the first cut was taken when the first node was detected for about half of the cultivars. The second and third samplings for the first cut were taken at the early and late silage maturity stages (corresponding to the ear emergence), respectively. The second cut was also designed to have 3 samplings (first sampling occurred usually in one corner of the plot and third sampling next to it; the sampling number and cuts are depicted in Table 2). The samplings of the second cut were performed 35 up to 44 days after the samplings within the first cut.

Table 1. Genotypes included in the study

Tabelle 1. Liste der in der Studie verwendeten Sorten

\begin{tabular}{|c|c|c|}
\hline Genotype & Heading date* & Registration year \\
\hline 1 & 54 & 1993 \\
\hline 2 & 56 & 1997 \\
\hline 3 & 58 & 1987 \\
\hline 4 & 63 & 1995 \\
\hline 5 & 53 & $\dagger$ \\
\hline 6 & 53 & $\dagger$ \\
\hline 7 & 62 & $\dagger$ \\
\hline 8 & 63 & $\dagger$ \\
\hline 9 & 61 & 2005 \\
\hline 10 & 55 & 1999 \\
\hline 11 & 60 & 2003 \\
\hline 12 & 62 & 2004 \\
\hline 13 & 63 & 2009 \\
\hline 14 & 55 & 2008 \\
\hline 15 & 61 & $\dagger$ \\
\hline 16 & 64 & $\dagger$ \\
\hline 17 & 54 & 2007 \\
\hline 18 & 55 & $\dagger$ \\
\hline 19 & 55 & 2007 \\
\hline 20 & 56 & 2007 \\
\hline
\end{tabular}

Table 2. Harvesting schedule for the two experimental seasons Tabelle 2. Erntetermine für die zwei Versuchsjahre

\begin{tabular}{|c|c|c|c|}
\hline Cut & Sampling number & Year 1 & Year 2 \\
\hline \multirow{3}{*}{1} & 1 & 15 May & 08 May \\
\hline & 2 & 29 May & 13 May \\
\hline & 3 & 09 June & 23 May \\
\hline \multirow{3}{*}{2} & 1 & 28 June & 18 June \\
\hline & 2 & 03 July & 22 June \\
\hline & 3 & 11 July & 03 July \\
\hline 3 & 1 & 23 Aug. & 17 Aug. \\
\hline 4 & 1 & 10 Oct. & 10 Oct. \\
\hline
\end{tabular}

At the time of sampling, the grass was cut manually to $5 \mathrm{~cm}$ stubble height. The actual sampling area within each plot varied between 0.25 and $0.5 \mathrm{~m}^{2}$ depending on the amount of above ground biomass. After the third sampling within the first and second cut, the remainder of the plot was harvested with a Haldrup plot-harvester to $5 \mathrm{~cm}$ stubble height. All forage from the sample area within each plot was weighed to quantify the fresh herbage weight. A representative sub-sample was then dried at $60^{\circ} \mathrm{C}$ reaching a constant weight to determine the dry matter (DM) content for laboratory analysis.

\subsection{Morphological measurements}

The phenological stage of the plants was quantitatively monitored at each sampling date by cutting a representative sample of around 50 tillers randomly from each plot to ground level. Tillers were classified according to the 17 stages of development described by Park (1980) as presented in Table 3. In both years, only 10 stages, namely those from 3 to 12 , were detected in the experimental plots. Numerical indices for quantifying the phenological development included two different approaches. Firstly, the Mean Stage by Count (MSC), representing the reference method, was calculated as the average of the individual stage categories present in the herbage sample, weighted for the number of tillers at each stage (Moore et al., 1991):

$M S C=\frac{\sum_{i}^{n} S_{i} \cdot N_{i}}{C}$

where $S_{i}=$ stage number, $N_{i}=$ number of tillers in stage $S_{i}$, and $\mathrm{C}=$ total number of tillers in herbage sample.

In the second approach, the percentage of tillers above a given developmental stage $i$ as defined according to Park 
Table 3. Classification of Lolium perenne L. developmental stages according to Park (1980)

Tabelle 3. Klassifizierung des Entwicklungsstadiums von Lolium perenne L. nach Park (1980)

\begin{tabular}{lll}
\hline Code & Abbreviation & Description \\
\hline 1 & S0 & No elongated leaf sheath \\
2 & S1 & 1 elongated leaf sheath (1 fully developed leaf) \\
3 & S2 & 2 elongated leaf sheaths (2 fully developed leafs) \\
4 & S3 & 3 or more elongated leaf sheaths (3 fully developed leafs) \\
5 & K1 & 1 tactile node \\
6 & K2 & 2 tactile nodes \\
7 & K3 & 3 or more tactile nodes \\
8 & B & Swelling of the upper leaf sheath indicating presence of the inflorescence inside it (boot stage) \\
9 & G1.1 & Beginning of heading, the upper 1-2 cm of the inflorescence is visible \\
10 & G1.5 & 50\% of the inflorescence emerged \\
11 & G1.9 & The inflorescence fully emerged and the inflorescence peduncle is visible \\
12 & OH & Inflorescence peduncle fully emerged \\
13 & G2.1 & Beginning of flowering (anthesis), some anthers are visible \\
14 & G2.5 & Full flowering, maximum number of anthers are visible \\
15 & G2.9 & End of flowering, only few anthers are still visible \\
16 & G3 & Milk ripe \\
17 & & Dough ripe \\
\hline
\end{tabular}

(1980) was calculated, where $i$ varied between the first and the last of the observed stages, resulting in a total of 10 different simple maturity indices $\left(\mathrm{SMI}_{i}\right)$, which were later on tested for their suitability:

$S M I_{i}=\frac{\sum_{i}^{n} N_{i}}{C}$

where $\mathrm{SMI}_{i}=$ Simple Maturity Index beginning from stage $i, \mathrm{~N}_{i}=$ number of tillers in stage $i$, and $\mathrm{C}=$ total number of tillers in herbage sample.

\subsection{Analytical procedures}

The dried sub-samples were uniformly ground using a Cyclotec 1093 sample mill (Foss, Sweden) to a particle size of $1 \mathrm{~mm}$. All available samples were scanned twice using NIR-Systems 5000 monochromator (Perstrop Analytical Inc., Silver Spring, MD 20904, USA), where the software (ISI version) for data collection and manipulation was supplied by Infrasoft International (ISI, Port Matilda, PA, USA). Calibration and validation subsets were relatively small in number, with 36 and 30 calibration samples, and 14 and 20 validation samples in year 1 and 2, respectively, since an already existing NIRS calibration was refined.
The concentrations of neutral detergent fiber (NDF), acid detergent fiber $(\mathrm{ADF})$ and acid detergent lignin $(\mathrm{ADL})$ were determined sequentially as described by Van Soest et al. (1991) using the semiautomatic ANKOM ${ }^{220}$ Fiber Analyzer (ANKOM Technology, Macedon, NY, USA). NDF and ADF were analyzed without a heat stable amylase and expressed inclusive of residual ash, while ADL content was corrected after the residual ash content. The in vitro cellulase technique developed by De Boever et al. (1988) was used to determine the digestibility of herbage samples. The percentage of digestible organic matter (DOM) was then calculated by applying the following equation of Weissbach et al. (1999):

$\operatorname{DOM}(\%)=100 \times(940-\mathrm{CA}-0.62 \times$ EULOS -0.000221

$\left.\times \mathrm{EULOS}^{2}\right) /(1000-\mathrm{CA})$

where $\mathrm{CA}=$ crude ash and EULOS = enzyme insoluble organic matter; CA and EULOS are expressed in $\mathrm{g} \mathrm{kg}^{-1} \mathrm{DM}$. Calibrations were later developed by regressing the laboratory-determined values of sample subsets against the NIR spectral data. Means and ranges as well as coefficients of correlation and standard errors of calibration and validation for the investigated quality parameters are presented in Table 4.

\subsection{Statistical procedures}

The data from both growing seasons were averaged, because the 'year' includes two aspects, namely climatic con- 
ditions and sward age, which cannot be separated from each other statistically.

To develop a simple maturity index $\left(\mathrm{SMI}_{i}\right)$ to quantify the developmental stage of a perennial grass sward, correlations between the tested maturity indices, that is, MSC and $\mathrm{SMI}_{i}$ (with $i$ between three and twelve), on the one hand and yield and forage quality traits $(\mathrm{NDF}, \mathrm{ADF}, \mathrm{ADL}$ and DOM) on the other hand, were computed using Spearman's rank correlation coefficient in SAS 9.1 PROC CORR (SAS Institute, 2000) as the data were not normally distributed (Table 5). Coefficients were calculated on data that were averaged over year and replicate.

To explore and compare the behavior of treatments and their influence on the studied yield and quality parameters in the presence and absence of the maturity index as a covariable (i.e., the $\mathrm{SMI}_{i}$ ), the statistical analysis was conducted twice with PROC MIXED for a randomized complete block design. The analysis without the covariable included cut, sampling date, genotype and block, as well as their interactions, as fixed effects. The second analysis was done in presence of the covariable expressed through its main effect. In both analyses, cut $\times$ sampling date was treated as a repeated measure and analyzed using the unstructured (UN) covariance structure and the REPEATED statement in PROC MIXED. Least square means were separated by the SAS PDIFF option in PROC MIXED. Significance was declared at $P<0.05$ and adjusted using Bonferroni-Holm procedure (Holm, 1979).

\section{Results}

\subsection{Relationship between maturity indices and yield and quality traits}

The correlation between MSC and the tested quality parameters reached the level of significance for the three sampling dates within the first cut, in addition to the first and second sampling dates within the second cut (Table 5). In the third sampling date within the second cut, MSC was significantly correlated only to ADL and DOM contents. Correlation was non-significant between MSC and yield in both cuts. Correlation analyses between the percentage of tillers above a given development stage and the investigated parameters revealed that considering the percentage of tillers above the boot stage (stage 8 -SMI8, Table 3) showed comparable significances and magnitude of correlations to that produced from the MSC for both cuts and all sampling dates. Correlation coefficients clearly fluctuated for the quality parameters and reached mostly the highest values in case of the DOM. Generally, higher correlation coefficients were observed for the first rather than for the second cut.

\subsection{Impact of the simplified maturity index on yield and quality evaluation}

As a result of the correlation analyses, it was decided to include the SMI8 as a covariable in the analysis of variance and run the statistical analysis twice, with and without the covariable, to explore its influence on the impact of genotype, cut, sampling date and their interaction on the studied parameters, as mentioned above. Only the effects including genotypic variations will be presented and discussed in detail.

The analysis of variance performed without using SMI8 as covariable is presented in Table 6 . The genotype $\times$ cut interaction was observed with respect to the fiber fractions and yield. However, it turned non-significant in case of yield after correcting with Bonferroni-Holm test. Except for the ADL content, the cut $\times$ sampling date interaction influenced all the other parameters.

Table 7 presents the combined analysis of variance considering the covariable SMI8. Concerning the two-way interactions, a similar trend to that illustrated in Table 6 was observed, where the genotype interacted with the cut for the fiber fractions, while the cut $\times$ sampling date

Table 4. Statistical data of the calibration of NIRS for NDF, ADF, ADL and DOM of the investigated genotypes

Tabelle 4. NIRS Kalibrationsstatistik für NDF, ADF, ADL und VOM der untersuchten Sorten

\begin{tabular}{llcccrr}
\hline Parameter $\left(\mathrm{g} \mathrm{kg}^{-1}\right)$ & $\mathrm{n} \dagger$ & Mean & Range & $\mathrm{R}^{2}$ & SEC & SEV \\
\hline NDF & 96 & 566.5 & $413.9-692.6$ & 0.93 & 16.00 & 20.79 \\
ADF & 92 & 280.0 & $173.5-362.7$ & 0.97 & 7.03 & 10.28 \\
ADL & 63 & 20.0 & $3.7-41.1$ & 0.54 & 5.60 & 5.32 \\
DOM & 99 & 768.7 & $610.0-897.1$ & 0.98 & 9.90 & 15.50 \\
\hline
\end{tabular}

$\dagger \mathrm{n}$ : number of samples; SEC: Standard error of calibration; SEV: Standard error of validation 


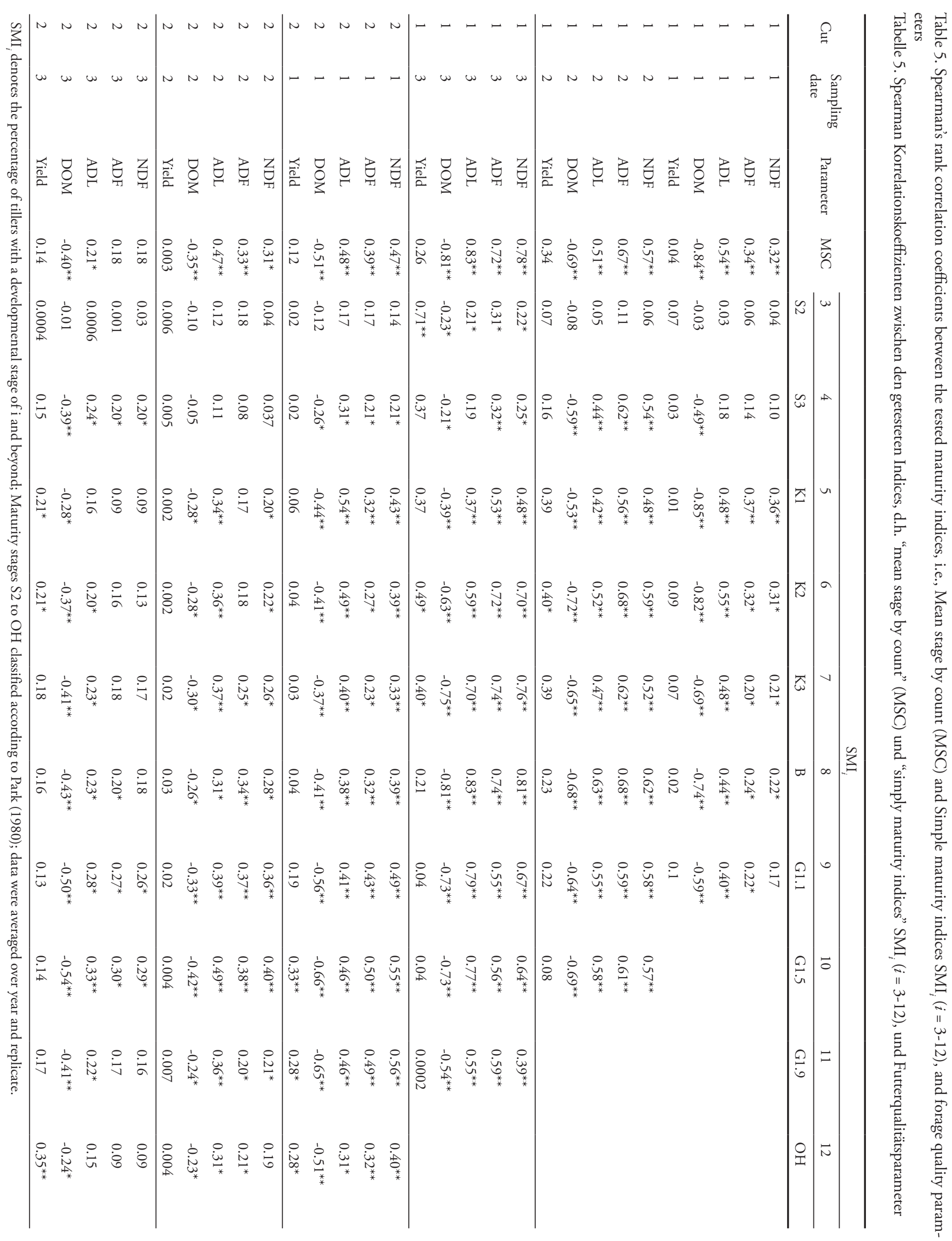


Table 6. F-values of genotype, sampling date, cut and their interactions on yield and feed quality parameters without using covariable (SMI8)

Tabelle 6. F-Werte für Sorte, Erntetermin, Aufwuchs und Wechselwirkungen für Ertrag und Futterqualität ohne Kovariable (SMI8)

\begin{tabular}{|c|c|c|c|c|c|}
\hline \multirow{2}{*}{ Factor } & \multirow{2}{*}{ Dry matter yield $\left(\mathrm{t} \mathrm{ha}^{-1}\right)$} & NDF & $\mathrm{ADF}$ & $\mathrm{ADL}$ & \multirow[t]{2}{*}{ DOM } \\
\hline & & & 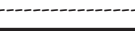 & 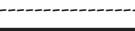 & \\
\hline Genotype (G) & 1.70 & $8.95^{* * *}$ & $7.23^{* * *}$ & $6.67^{* * *}$ & $16.21^{* * *}$ \\
\hline Cut (C) & 0.00 & $688.95^{* * *}$ & $460.61^{* * *}$ & $391.26^{* * *}$ & $759.43^{* * *}$ \\
\hline Sampling date (SD) & $367.78^{* * *}$ & $179.69^{* * *}$ & $366.78^{* * *}$ & $105.18^{* * *}$ & $1144.59^{* * *}$ \\
\hline Block & 0.07 & $14.95^{* * *}$ & $13.79^{* * *}$ & 2.70 & 0.84 \\
\hline $\mathrm{G} \times \mathrm{C}$ & $2.07 \dagger$ & $2.89^{* *}$ & $2.68^{* *}$ & $3.44^{* * *}$ & $5.17^{* * *}$ \\
\hline $\mathrm{G} \times \mathrm{SD}$ & 1.48 & 0.77 & 0.91 & 1.13 & 1.39 \\
\hline $\mathrm{C} \times \mathrm{SD}$ & $109.45^{* * *}$ & $18.14^{* * *}$ & $47.64^{* * *}$ & 1.58 & $46.50^{* * *}$ \\
\hline $\mathrm{G} \times \mathrm{C} \times \mathrm{SD}$ & 0.89 & 0.98 & 1.07 & 1.16 & 1.59 \\
\hline
\end{tabular}

** Significant at 0.01 level of probability.

*** Significant at 0.001 level of probability.

$\dagger$ Non-significant after applying Bonferroni-Holm test.

influenced both the yield and fiber fractions. The results confirm the hypothesis that the covariable SMI8 exerted a significant influence on yield and quality measurements. The slopes reported in the table show that each unit's increase in the covariable SMI8 caused an increase of 0.90 , $0.30,0.30$ and 0.05 units in the yield $\left(\mathrm{t} \mathrm{ha}^{-1}\right)$, NDF, ADF and ADL $\left(\mathrm{g} \mathrm{kg}^{-1}\right)$, respectively, as well as a decrease of 0.43 units in the amount of DOM $\left(\mathrm{g} \mathrm{kg}^{-1}\right)$.

The comparison of means for the genotype $\times$ cut interaction of NDF and ADF contents are displayed in Table 8 for both analyses, that is, with or without covariable. The inclusion of the covariable resulted in several effects. While in the first cut, no significant genotype effect was left at all after considering the covariable, the larger effects were observed in the second cut. Firstly, the difference between the maximum and minimum NDF contents amounted to 57.2 and $55.2 \mathrm{~g} \mathrm{NDF} \mathrm{kg}^{-1}$ for the second cut without and with the contribution of the covariable, respectively. The same applied to the ADF content, where the range amounted to 41.2 and $36.4 \mathrm{~g} \mathrm{ADF} \mathrm{kg}^{-1}$ for the second cut without and with considering the covariable, respectively. The inclusion of the covariable reduced the variation ac-

Table 7. F-values of genotype, sampling date, cut and their interactions on yield and forage quality parameters with covariable (SMI8) Tabelle 7. F-Werte für Sorte, Erntetermin, Aufwuchs und Wechselwirkungen für Ertrag und Futterqualität mit Kovariable (SMI8)

\begin{tabular}{|c|c|c|c|c|c|}
\hline Factor & Dry matter yield $\left(\mathrm{t} \mathrm{ha}^{-1}\right)$ & NDF & $\mathrm{ADF}$ & $\mathrm{ADL}$ & DOM \\
\hline Genotype (G) & 1.47 & $6.78^{* * *}$ & $5.35^{* * *}$ & $4.42^{* * *}$ & $8.78^{* * *}$ \\
\hline Cut $(\mathrm{C})$ & 0.06 & $775.99^{* * *}$ & $526.60^{* * *}$ & $493.86^{* * *}$ & $980.28^{* * *}$ \\
\hline Sampling date (SD) & $122.78^{* * *}$ & $87.94^{* * *}$ & $167.79^{* * *}$ & $44.71^{* * *}$ & $278.84^{* * *}$ \\
\hline Block & 0.15 & $15.94^{* * *}$ & $14.97^{* * *}$ & 2.53 & 1.26 \\
\hline Covariable (SMI8) & $8.64^{* *}$ & $8.95^{* *}$ & $15.41^{* * *}$ & $12.27^{* *}$ & $20.65^{* * *}$ \\
\hline $\mathrm{G} \times \mathrm{C}$ & 1.54 & $2.09^{*}$ & $2.00^{*}$ & $2.19^{*}$ & $3.80^{* * *}$ \\
\hline $\mathrm{G} \times \mathrm{SD}$ & 1.35 & 0.74 & 0.90 & 0.97 & 1.21 \\
\hline $\mathrm{C} \times \mathrm{SD}$ & $65.34^{* * *}$ & $7.62^{* *}$ & $23.69^{* * *}$ & $3.51^{*}$ & $12.58^{* * *}$ \\
\hline $\mathrm{G} \times \mathrm{C} \times \mathrm{SD}$ & 1.03 & 1.04 & 1.11 & 1.15 & 1.60 \\
\hline Slope & 0.90 & 0.30 & 0.30 & 0.05 & -0.43 \\
\hline
\end{tabular}

* Significant at 0.05 level of probability.

** Significant at 0.01 level of probability.

*** Significant at 0.001 level of probability.

SMI8 represents the percentage of tillers beyond the boot stage in the herbage sample. Slope represents degree of dependency of the yield and quality parameters on the covariable. 


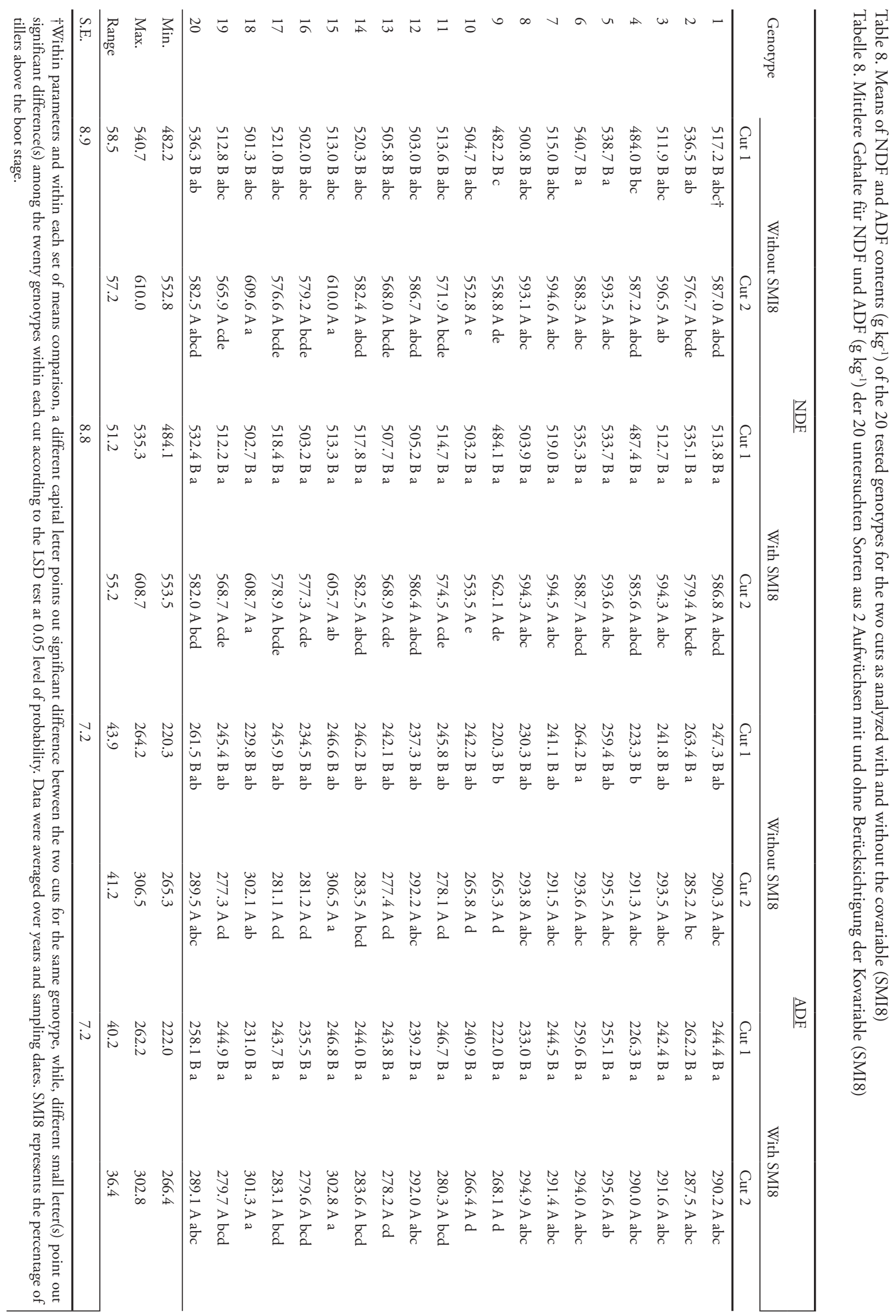


counted for the development stage on NDF and ADF content. Secondly, it was detected that the inclusion of the covariable affected the significances among the genotypes within the second cut, modifying the ranking of genotypes from the highest to the lowest content of NDF and ADF. Similar results could be observed for ADL and DOM $\left(\mathrm{g} \mathrm{kg}^{-1}\right)$, as shown in Table 9. The difference between the maximum and minimum ADL content in the first cut amounted to $6.0 \mathrm{~g} \mathrm{~kg}^{-1}$ without the covariable but only $4.7 \mathrm{~g} \mathrm{~kg}^{-1}$ after including it. The inclusion of the covariable reduced the variation accounted for the development stage on ADL content and DOM. Likewise, the ranking of genotypes changed for ADL and DOM after introducing the covariable in cut 1 , while in cut 2 this effect was not observed. Nonetheless, the covariable did not contribute substantially in changing the ranking of the genotypes in both ADL and DOM within a cut. Generally, we observed higher contents of fiber fractions and consequently a lower digestibility in the second compared to the first cut.

\section{Discussion}

Herbage maturity can influence forage yield and quality substantially. Therefore, an important concern in this research was to identify an accurate and simple criterion for maturity quantification of a homogeneous sward.

\subsection{Selection basis of the simple maturity index (SMI8)}

Analysis of correlations between growth stages and yield and constituents of nutritive value (Table 5) revealed variable correlation coefficients, with the percentage of tillers at or beyond the boot phase. Our simplified numerical maturity index SMI8 provided similar correlations to the studied parameters as the mean stage by count (MSC). This was in agreement with the findings of Ansquer et al. (2009), who identified three phenological stages, namely the start of stem elongation, flowering, and seed ripening, as key to manage dynamics of growth and demography of temperate grassland species. Similarly, Mika (1983) found that cultivar differences in timothy were more pronounced at ear emergence than at later sampling dates suggesting that a sampling date at or near the ear emergence is to be preferred for routine evaluation. Our results using SMI8 support this observation.

Maturity ratings in the current study were based on individual tillers, which proved to be an accurate method for quantifying the different developmental stages in herbage samples. However, Van Santen and Casler (1990b), in comparing the individual tiller versus the whole plant in maturity rating, suggested that the maturity can effectively be rated using the simpler whole plant visual rating. This conclusion, however, maybe misleading since their tiller samples comprised only the five most mature individual tillers, which may not be considered as representative. A larger random sample, as in our study, might have avoided this bias.

The covariable SMI8 affected all the studied parameters, where a main effect was always detected. This suggests that the maturity aspect was reflected in distinctive morphological development and nutritive value (Cop et al., 2009). Relationships between morphological stage and nutritive value of herbage for livestock are well documented (Sanderson and Wedin, 1989; Valente et al., 2000; Jeangross et al., 2001; Pontes et al., 2007).

\subsection{Impact of the simple maturity index (SMI8) on yield and nutritive value}

The analysis of variance (Table 7) highlighted a relatively strong influence of the covariable on yield, but a relatively low impact on the quality parameters, as indicated by the slopes. We suggest that this low effect in case of the quality parameters was in part due to the design of the combined analysis which involved two cuts with three sampling dates each. This structure may have partially contributed to mask the impact of the covariable, where the magnitude of effect of the studied covariate was dependent on other components of the analysis of variance and their interactions. Therefore, an additional analysis was conducted using a simpler statistical model, exemplified for the DOM content, and the results are shown in Tables 10 and 11 . Only the second sampling date in each cut was considered, and the two cuts were analyzed separately with and without the covariable. The second sampling date, done at an early silage maturity, was chosen because it represents the developmental stage at which grasses are commonly harvested in intensive dairy farming systems.

It becomes evident that, in the first cut, the genotypes were variable in their DOM contents. After considering the covariable, the variation in DOM content was not significant among the 20 genotypes, suggesting that the development stage is largely responsible for the variation in DOM content (Table 11). Despite the different basis of the comparison that resulted from simplifying the structure of the 


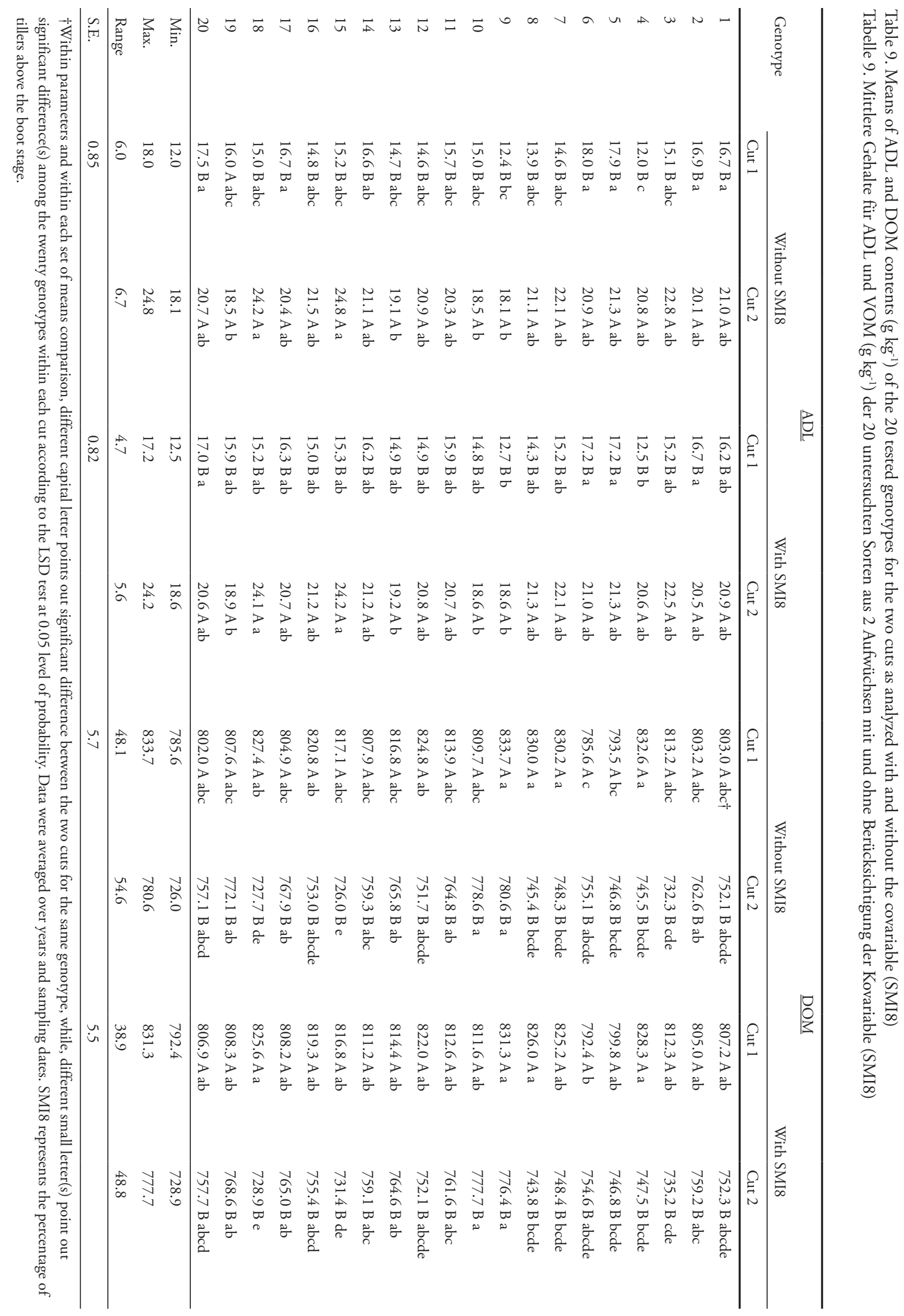


Table 10. Genotypic influence on DOM $\left(\mathrm{g} \mathrm{kg}^{-1}\right)$ in absence and presence of the covariable (SMI8) for the $2^{\text {nd }}$ sampling date within $1^{\text {st }}$ and $2^{\text {nd }}$ cuts

Tabelle 10. Einfluss der Sorte auf die VOM $\left(\mathrm{g} \mathrm{kg}^{-1}\right)$ mit oder ohne Berücksichtigung der Kovariable (SMI8) für den 2. Erntetermin des 1. und 2. Aufwuchses

\begin{tabular}{lllll}
\hline \multirow{2}{*}{ Effect } & \multicolumn{3}{c}{$1^{\text {st }}$ Cut } & Cut \\
\cline { 2 - 5 } & Without SMI8 & With SMI8 & Without SMI8 & With SMI8 \\
\hline Genotype & $3.39^{* * *}$ & 1.21 & $6.57^{* * *}$ & $5.45^{* * *}$ \\
Block & 0.91 & 0.69 & 1.84 & 1.80 \\
Covariable (B) & & $8.60^{* *}$ & & 2.25 \\
\hline Slope & & -0.70 & & -0.28 \\
\hline
\end{tabular}

SMI8 represents the percentage of tillers above the boot stage in the herbage sample. Slope represents degree of dependency of the yield and quality parameters on the covariable.

new analysis of variance, comparing the slope in Table 7 $(-0.43)$ with the newly calculated slope in Table $10(-0.70)$ approves the hypothesis that the magnitude of the effect of covariable changed as the design of the analysis of variance changed. With the new slope, the correlation between the covariable and the DOM content is getting closer to that achieved from the correlation analysis in Table 5. First cut DOM means listed in Table 11 confirm the contribution of the covariable in minimizing the variations among the genotypes (from 56.1 to $33.6 \mathrm{~g} \mathrm{~kg}^{-1}$ before and after considering the SMI8).

A different situation was observed in the case of the second cut, where the variations among the 20 tested genotypes remained after considering the covariable by 55.2 to $54.2 \mathrm{~g} \mathrm{~kg}^{-1}$ (Table 11). Since the reproductive tillers are the main component of the covariable SMI8, its effect will become weaker and less distinguishable as the number of reproductive tillers decrease, which is clearly observed in the second cut.

\section{Conclusion}

In the present study, a simplified maturity index (SMI8) to quantify the morphological development of perennial forage grass sward has been evaluated. The SMI8, expressed as the percentage of tillers beginning the boot stage, provided similar correlations to the yield and studied quality attributes as the mean stage by count (MSC), but it was less time consuming and can be applied routinely and easily under field conditions.

Testing the yield and quality performance of the genotypes, with and without including the SMI8 in the analysis, revealed that the variations among the genotypes were masked. The inclusion of the covariable reduced the variation accounted for the development stage on NDF and
ADF contents. It modified the ranking of genotypes from the highest to the lowest content of NDF and ADF. This suggests that these variations were attributed only to the differences in development stage, which may change the ranking among genotypes for certain traits. Therefore, it is recommended to include the SMI as a basic criterion during the evaluation of genotypes.

\section{Acknowledgment}

We would like to thank Dr. Ralf Loges for carrying out the NIRS calibrations for the data and Dr. Mario Hasler for his helpful discussions on the statistical analysis of the data. Many thanks are, as well, due to Mrs. Karin Makoben for her help in the laboratory analysis. We are also grateful to Dr. U. Feuerstein and Dr. D. Stelling (Euro Grass B.V.), as well as to Dr. B. Ingwersen and W. Luesink (Norddeutsche Pflanzenzucht Hans-Georg Lembke KG), for the fruitful discussions during preparation of the paper. This research was financially supported by the German Academic Exchange Service (DAAD) and the Innovationsstiftung Schleswig-Holstein.

\section{References}

Ansquer, P., Al Haj Khaled, R., Cruz, P., Theau, J.-P., Therond, O. and M. Duru (2009): Characterizing and predicting plant phenology in species-rich grasslands. Grass and Forage Science 64, 57-70.

Brueland B.A., Harmoney, K.R., Moore, K.J., George, J.R. and E.C. Brummer (2003): Developmental morphology of smooth bromegrass growth following spring grazing. Crop Science 43, 1789-1796. 
Table 11. Means of DOM $\left(\mathrm{g} \mathrm{kg}^{-1}\right)$ of the 20 tested genotypes for the $2^{\text {nd }}$ sampling date within $1^{\text {st }}$ and $2^{\text {nd }}$ cuts as analysed with and without the covariable (SMI8)

Tabelle 11. Mittlere VOM ( $\left.\mathrm{g} \mathrm{kg}^{-1}\right)$ der 20 untersuchten Sorten für den 2. Erntetermin des 1. und 2. Aufwuchses mit oder ohne Berücksichtigung der Kovariable (SMI8)

\begin{tabular}{|c|c|c|c|c|}
\hline \multirow{2}{*}{ Genotype } & \multicolumn{2}{|c|}{$1^{\text {st }} \mathrm{Cut}$} & \multicolumn{2}{|c|}{$2^{\text {nd }} \mathrm{Cut}$} \\
\hline & Without SMI8 & With SMI8 & Without SMI8 & With SMI8 \\
\hline 1 & $813.2 \mathrm{abc} \dagger$ & 820.9 a & $757.0 \mathrm{bcd}$ & 757.5 bcde \\
\hline 2 & $809.5 \mathrm{abc}$ & $810.4 \mathrm{a}$ & $771.9 \mathrm{abc}$ & $771.6 \mathrm{abcd}$ \\
\hline 3 & $818.9 \mathrm{abc}$ & $815.3 \mathrm{a}$ & $752.6 \mathrm{~cd}$ & 752.1 bcde \\
\hline 4 & $844.4 \mathrm{a}$ & $838.1 \mathrm{a}$ & $750.2 \mathrm{~cd}$ & 750.2 cde \\
\hline 5 & $801.0 \mathrm{bc}$ & $812.5 \mathrm{a}$ & $757.3 \mathrm{abcd}$ & 758.1 bcde \\
\hline 6 & $788.3 \mathrm{c}$ & $804.5 \mathrm{a}$ & $765.8 \mathrm{abcd}$ & 766.2 abcde \\
\hline 7 & $839.6 \mathrm{ab}$ & $829.5 \mathrm{a}$ & $755.5 \mathrm{bcd}$ & 757.6 bcde \\
\hline 8 & $838.4 \mathrm{ab}$ & $827.4 \mathrm{a}$ & $748.7 \mathrm{~cd}$ & 747.0 de \\
\hline 9 & $842.2 \mathrm{ab}$ & $835.8 \mathrm{a}$ & $786.0 \mathrm{ab}$ & $783.2 \mathrm{ab}$ \\
\hline 10 & $813.6 \mathrm{abc}$ & $818.4 \mathrm{a}$ & $789.5 \mathrm{a}$ & $791.1 \mathrm{a}$ \\
\hline 11 & $816.1 \mathrm{abc}$ & $812.5 \mathrm{a}$ & $776.3 \mathrm{abc}$ & $775.1 \mathrm{abcd}$ \\
\hline 12 & $828.1 \mathrm{abc}$ & $821.2 \mathrm{a}$ & $768.6 \mathrm{abc}$ & 768.5 abcde \\
\hline 13 & $831.6 \mathrm{ab}$ & $827.4 \mathrm{a}$ & $774.6 \mathrm{abc}$ & $772.6 \mathrm{abcd}$ \\
\hline 14 & $810.6 \mathrm{abc}$ & $818.5 \mathrm{a}$ & $770.2 \mathrm{abc}$ & 769.4 abcde \\
\hline 15 & $829.1 \mathrm{abc}$ & $823.0 \mathrm{a}$ & $735.1 \mathrm{~d}$ & $737.8 \mathrm{e}$ \\
\hline 16 & $830.4 \mathrm{abc}$ & $823.7 \mathrm{a}$ & $760.0 \mathrm{abcd}$ & 760.3 abcde \\
\hline 17 & $809.3 \mathrm{abc}$ & $815.6 \mathrm{a}$ & $780.3 \mathrm{abc}$ & $779.3 \mathrm{abc}$ \\
\hline 18 & $831.8 \mathrm{ab}$ & $826.5 \mathrm{a}$ & $734.3 \mathrm{~d}$ & $736.9 \mathrm{e}$ \\
\hline 19 & $814.8 \mathrm{abc}$ & $815.6 \mathrm{a}$ & $780.9 \mathrm{abc}$ & $779.2 \mathrm{abc}$ \\
\hline 20 & $818.9 \mathrm{abc}$ & $833.0 \mathrm{a}$ & $759.9 \mathrm{abcd}$ & 760.9 abcde \\
\hline Min. DOM content & 788.3 & 804.5 & 734.3 & 736.9 \\
\hline Max. DOM content & 844.4 & 838.1 & 789.5 & 791.1 \\
\hline Range & 56.1 & 33.6 & 55.2 & 54.2 \\
\hline S.E. & 8.0 & 9.1 & 6.0 & 6.2 \\
\hline
\end{tabular}

$\dagger$ Means followed by the same letter(s) within the same column are not significantly different according to the LSD test at 0.05 level of probability. SMI8 represents the percentage of tillers above the boot stage.

Cop, J., Lavrencic, A. and K. Košmelj (2009): Morphological development and nutritive value of herbage in five temperate grass species during primary growth: analysis of time dynamics. Grass and Forage Science 64, 122-131.

De Boever J.L., Cottyn, B.L., Andries, J.I., Buysse, F.X. and J.M. Vanacker (1988): The use of cellulase technique to predict digestibility, metabolizable and net energy of forages. Animal Feed Science and Technology 19, 247-260.

Haun, J.R. (1973): Visual quantification of wheat development. Agronomy Journal 65, 116-119.
Holm, S. (1979): A simple sequentially rejective multiple test procedure. Scandinavian Journal of Statistics 6, 65-70.

Jeangross B., Scehovic, J., Schubiger, F.X., Lehmann, J., Daccord, R. and Y. Arrigo (2001): Nährwert von Wiesenpflanzen: Trockensubstanz-, Rohprotein- und Zuckergehalte. Agrarforschung 8, 79-86.

Kalu, B.A. and G.W. Fick (1981): Quantifying morphological development of alfalfa for studies of herbage quality. Crop Science 21, 267-271.

Mika, V. (1983): A comparison of the nutritive values of early and late varieties of timothy. Grass and Forage Science 38, 67-71. 
Moore, K.J. and L.E. Moser (1995): Quantifying developmental morphology of perennial grasses. Crop Science 35, 37-43.

Moore, K.J., Moser, L.E., Vogel, K.P., Waller, S.S., Johnson, B.E. and J.F. Pedersen (1991): Describing and quantifying growth stages of perennial forage grasses. Agronomy Journal 83, 1073-1077.

Park, B.-H. (1980): Untersuchungen zum Entwicklungsverlauf im Primäraufwuchs von perennierenden Futtergräsern. Dissertation, Universität Gießen.

Pontes, L.S., Carrère, P., Andueza, D., Louault, F. and J.F. Soussana (2007): Seasonal production nutritive value of temperate grasses found in semi-natural pastures in Europe: responses to cutting frequency and $\mathrm{N}$ supply. Grass and Forage Science 62, 485-496.

Sanderson, M.A. (1992): Morphological development of switch grass and kleingrass. Agronomy Journal 84, 415-419.

Sanderson, M.A. and W.F. Wedin (1989): Phenological stage and herbage quality relationships in temperate grasses and legumes. Agronomy Journal 81, 864-869.

SAS Institute, Inc. (2000): SAS/STAT User's Guide, Version 9.1 SAS Institute, Cary, NC.

Simon, U. and B.H. Park (1983): A descriptive scheme for stages of development in perennial forage grasses. In: Smith, J.A. and V.W. Hays (Eds.): Proceedings of the $14^{\text {th }}$ International Grassland Congress, Lexington, KY, 15-24 June 1981. Westview Press, Boulder, CO, pp. 416-418.

Sweet, N., Wiltshire, J.J.J. and C.K. Baker (1991): A new descriptive scale for early reproductive development in Lolium perenne L. Grass and Forage Science 46, 201206.
Valente, M.E., Borreani G., Peiretti, P.G. and E. Tabacco (2000): Codified morphological stage for predicting digestibility of Italian ryegrass during the spring cycle. Agronomy Journal 92, 967-973.

Van Santen, E. and M.D. Casler (1990a): Methods for visually rating maturity in tetraploid Dactylis L. Plant Breeding 105, 26-32.

Van Santen, E. and M.D. Casler (1990b): Forage quality traits and dry matter yield in $4 \mathrm{x}$ progeny from interploidy crosses in Dactylis L. Crop Science 30, 35-39.

Van Soest, P.J. (1994): Nutritional ecology of the ruminant. $2^{\text {nd }}$ ed., Cornell University Press, New York.

Van Soest, P.J., Robertson, J.B. and B.A. Lewis (1991): Methods for dietary fiber, neutral detergent fiber, and nonstarch polysaccharides in relation to animal nutrition. Journal of Dairy Science 74, 3583-3597.

Weissbach F., Kuhla, S. Schmidt, L. and A. Henkels (1999): Estimation of the digestibility and the metabolizable energy of grass and grass products. Proceedings of the Society of Nutrition Physiology 8, 72.

West, C.P. (1990): A proposed growth stage system for bermudagrass. In: Forages - sustaining food production and environmental quality. Proceedings of the American Forage and Grassland Conference, Blacksburg, VA, 6-9 June 1990. American Forage and Grassland Council, Georgetown, TX, pp. 38-42.

West, C.P., Walker, D.W., Bacon, R.K., Longer, D.E. and K.E. Turner (1991): Phenological analysis of forage yield and quality in winter wheat. Agronomy Journal 83, 217-224.

Zadoks, J.C., Chang, T.T. and C.F. Konzak (1974): A decimal code for the growth stages of cereals. Weed Research 14, 515-421. 